\title{
EFFECT OF PIROXICAM, METAMIZOL, AND S-ADENOSYLMETHIONINE IN A MURINE MODEL OF EXPERIMENTAL TRICHOMONIASIS
}

\author{
NOGAL-RUIZ J.J.*, GÓMEZ-BARRIO A.*, ESCARIO J.A.*, MONTERO-PEREIRA D.* \\ \& MARTÍNEZ-FERNÁNDEZ A.R.*
}

Summary:

Biological effects of piroxicam, metamizol, and S-adenosylmethionine (S-AMET) have been tested in NMRI mice infected intraperitoneally with Trichomonas vaginalis. An intraperitoneal treatment during ten preinfection days with piroxicam $110 \mathrm{mg} / \mathrm{Kg} /$ day), or metamizo (275 mg/Kg/day), but not with S-AMET (17 mg/ $\mathrm{Kg} /$ day) induced a significant decrease of abdominal lesions and mortality, assessed by means of a pathogenicity index. The trichomonicidal activity of piroxicam, metamizol, and S-AMET was tested in vitro at the concentration of $300 \mu \mathrm{M}$, but found ineffective. These assays have shown the usefulness of the experimental trichomoniasis model for the study of the immunomodulating activity of synthetic drugs.

KEY WORDS : Trichomonas vaginalis, piroxicam, metamizol, S-adenosylmethionine.
Résumé : EFFETS PHARMACOLOGIQUES DU PIROXICAM, DU MÉTAMIZOLE ET DE LA S-ADÉNOSYLMÉTHIONINE DANS UN MODÈLE DE TRICHOMONASE MURINE

Les effets pharmacologiques du piroxicam, du métamizol, et de la S-adénosylméthionine (S-AMET) sur la réponse immunitaire ont été examinés dans un modèle de pathogénie expérimentale de Trichomonas vaginalis $110^{7}$ trophozoites inoculés par voie intrapéritonéale) chez la souris NMRI, par l'étude des changements histopathologiques sur les organes abdominaux et de la mortalité. Un traitement préinfection par voie intrapéritonéale pendant dix jours avec le piroxicam $110 \mathrm{mg} / \mathrm{Kg} / j o u r)$ ou le métamizole $1275 \mathrm{mg} / \mathrm{Kg} /$ jour $)$ induit une diminution significative des lésions abdominales et de la mortalité. La S-AMET $177 \mathrm{mg} / \mathrm{Kg} / \mathrm{jour})$ ne produit pas cet effet. L'activité trichomonacide du piroxicam, du métamizole et de la S-AMET (300 NM) a été examinée in vitro, mais ces médicaments ont été trouvés inactifs. Ces essais montrent l'intérêt de ce modèle expérimental de trichomonase pour l'étude de l'activité immunomodulatrice des médicaments.

MOTS CLÉS : Trichomonas vaginalis, piroxicam, métamizole, S-adénosylméthionine.

inal organs (especially pancreatic and hepatic) or phlegmonous inflammatory changes and production of ascitic fluid whose extent is proportional to the level of virulence of the inoculated strain (Nogal-Ruiz et al., 1997). This T. vaginalis infection is also an experimental model to test the immunomodulating effect of drugs on the host immune response (Nogal-Ruiz et al., 2003a). Besides, we have studied the effect of different drugs (immunosuppressors and immunostimulants) in this model (Nogal-Ruiz et al., 2003b).

In this paper, we have assayed the potential immunomodulating effect of three drugs with different properties on the pathogenicity of $T$. vaginalis in our model of experimental trichomoniasis: (1) piroxicam as a nonsteroidal antiinflammatory drug (NSAID) that suppresses several inflammatory processes; (2) metamizol, a pyrazolone derivative, with analgesic, antipyretic and weak antiinflammatory properties (Levy et al., 1995); and (3) S-adenosylmethionine (S-AMET), which is involved in the synthesis of polyamines, the methylation of lipids, nucleic acids, and proteins (Tabor \& Tabor, 1984), and the transsulphuration pathway (Walker \& Barrett, 1997).

\footnotetext{
* Departamento de Parasitología, Facultad de Farmacia, Universidad Complutense, Madrid, Spain.

Correspondence: Juan José Nogal-Ruiz, Departamento de Parasitología, Facultad de Farmacia, Universidad Complutense, Pza. Ramón y Cajal s/n, 28040 Madrid, España.

Tel.: + 34913941818 - E-mail: jjnogal@yahoo.es
} 


\section{MATERIALS AND METHODS}

\section{PARASITES AND CULTURE}

T vaginalis strains C1-NIH (reference $\left.\mathrm{n}^{\circ} 30001\right)$ and JH31A n ${ }^{\circ} 4$ (reference $n^{\circ} 30326$ ) from the American Type Culture Collection (ATCC, Maryland, USA) were grown at $37^{\circ} \mathrm{C}$ with $5 \% \mathrm{CO}_{2}$ in Diamond medium (Trypticase-Yeast extract-Maltose) pH 6.2, supplemented with $10 \%$ of heat inactivated equine serum, penicillin $\mathrm{G}(100 \mathrm{IU} / \mathrm{ml})$, and streptomycin $(100 \mu \mathrm{g} / \mathrm{ml})$. Parasites are maintained in our laboratory by cryopreservation in liquid nitrogen.

\section{ANIMALS}

NMRI female mice $(25 \mathrm{~g})$ were purchased from Charles River (Barcelona, Spain). They were housed in our laboratory in a temperature $\left(22^{\circ} \mathrm{C}\right)$ and humidity controlled environment in plastic cages with wood shaving bedding under $12 \mathrm{~h}$ light-dark cycle. Throughout the experiments, mice were given to water and Panlab chow (Barcelona, Spain), ad libitum.

\section{DRUGS}

Piroxicam (MW: 331,4; Feldene ${ }^{\circledast}$, Pfizer S.A., Madrid, Spain), metamizol (MW: 311,4; Nolotil $^{\circledR}$, Europharma S.A., Madrid, Spain), and S-AMET (MW: 398,4; S.Amet ${ }^{\circledR}$, Europharma S.A., Madrid, Spain) were purchased and suspended in sterile distilled water.

\section{IN VIVO PHARMACOLOGICAL EFFECT}

The first series of experiences was performed in order to determine the pharmacological effect of such drugs in a model of experimental trichomoniasis. Three experimental groups $(n=10)$ were treated ip, during 10 days before infection, with 10 preinfection doses of piroxicam (10 mg/kg/day), metamizol (275 mg/kg/day), and S-AMET (17 mg/kg/day), according to doses used in scientific literature of similar assays.

For infecting experimental groups, T. vaginalis strain C1-NIH (reference $n^{\circ}$ 30001) were inoculated ip with a single dose of $10^{7}$ trichomonads in logarithmic phase from axenic cultures and resuspended in fresh medium. Beside, a control group was infected, but not treated. Mice died on the infection and killed under anaesthesia at day 15 postinfection were examined at necropsy for the presence of trichomonads and for gross-pathological changes in the abdominal cavity. Pathogenicity index (PI) was determined as previously (Nogal-Ruiz et al., 1997). Briefly, mortality (0-50 points), ascites (06 points), and the gross damage produced to the peritoneum (0-10 points), spleen/pancreas/stomach (012 points), and the visceral (0-10 points) and diaphragmatic liver side (0-12 points) were quantified. The PI was then calculated as the arithmetic mean of the values for each parameter (Table I). The results showed were obtained from two independent experiments.

\section{IN VITRO TRICHOMONICIDAL ACTIVITY}

The in vitro trichomonicidal activity of piroxicam, metamizol, and S-AMET was assayed on the T. vaginalis strain JH31A $n^{\circ} 4$ (reference $n^{\circ}$ 30326). The experiments were carried out in duplicate using glass tubes, containing 100,000 trichomonads/ $\mathrm{ml}$ in a final volume of $2 \mathrm{ml}$. The drugs to be tested were dissolved

\begin{tabular}{|c|c|}
\hline Pathological manifestations & Values assigned \\
\hline \multicolumn{2}{|l|}{$\begin{array}{l}\text { Mortaligy } \\
\text { (Davs p.i.) }\end{array}$} \\
\hline $3^{\circ}$ & 50 \\
\hline $4^{\circ}$ & 44 \\
\hline $5^{\circ}$ & 38 \\
\hline Every delay day & Discount 6 points \\
\hline$>10^{\circ}$ & 6 \\
\hline \multicolumn{2}{|l|}{ Ascites } \\
\hline$<1 \mathrm{~mL}$ & 2 \\
\hline $1-2 \mathrm{~mL}$ & 4 \\
\hline$>1 \mathrm{~mL}$ & 6 \\
\hline \multicolumn{2}{|l|}{ Peritoneum } \\
\hline $1-3 \mathrm{SN}$ & 2 \\
\hline Multiple SN and/or N1 & 4 \\
\hline Multiple N1 and/or N2 & 6 \\
\hline MN affecting pelvis & 8 \\
\hline MN affecting intestine and kidneys & 10 \\
\hline \multicolumn{2}{|l|}{ Spleen/Pancreas/Stomach } \\
\hline 1-3 SN and/or splenomegaly & 2 \\
\hline Multiple SN and/or N1 & 4 \\
\hline N2 & 6 \\
\hline $\mathrm{N} 3$ affecting more than 1 organ & 8 \\
\hline N4 & 10 \\
\hline N5 affecting liver and intestine & 12 \\
\hline \multicolumn{2}{|l|}{ Visceral liver side } \\
\hline $1-3 \mathrm{SN}$ & 2 \\
\hline N1 & 4 \\
\hline N2 & 6 \\
\hline N3 & 8 \\
\hline N4 & 10 \\
\hline \multicolumn{2}{|l|}{ Diaphragmatic liver side } \\
\hline $1-3 \mathrm{SN}$ and/or colour changes & 2 \\
\hline N1 & 4 \\
\hline N2 & 6 \\
\hline N3 & 8 \\
\hline N4 & 10 \\
\hline N5 & 12 \\
\hline
\end{tabular}

SN: Single necrosis; N1: Necrosis of 3-5 mm diameter; N2: Necrosis of 5-8 mm; MN: Multiple Necrosis; N3: Necrosis of 8-10 mm; N4; Necrosis of 10-15 mm; N5: Necrosis of more than $15 \mathrm{~mm}$ of diameter affecting the most organ surface.

Table I - Rating of pathological manifestations in mice infected by the intraperitoneal route with Trichomonas vaginalis. 
in dimethyl sulfoxide (DMSO) and added to the cultures at a concentration of $300 \mu \mathrm{M}$ in a volume of $4 \mu \mathrm{l}$, after $6 \mathrm{~h}$ starting the culture. In each experiment there were six control tubes, containing only the solvent, and six tubes for every concentration of the drugs to be tested. 24 and $48 \mathrm{~h}$ after incubation at $37^{\circ} \mathrm{C}$, viable organisms were counted by using the Neubauer chamber. metronidazole (MW: 171,16; Sigma-Aldrich, Madrid, Spain) was used as reference drug at concentrations of 12,6 , and $3 \mu \mathrm{M}$. Cytocidal and cytostatic activities were determined in relation with controls as previously reported (Herrero et al., 1992). Briefly, the cytocidal (\% CA) or cytostatic (\% ca) activities were calculated with respect to the growth rates (GR) as follows:

$$
\% \mathrm{CA}=\left[1-\left(\mathrm{GR}_{\mathrm{drug}} / \mathrm{GR}_{\text {control }}\right)\right] 100
$$

GR being the relation between the number of viable T. vaginalis at 24 or $48 \mathrm{~h}$, and the number counted at 0 h. If $\mathrm{GR}_{\mathrm{drug}} / \mathrm{GR}_{\text {control }}<1$ then it calculates \% CA or, on the contrary, if $\mathrm{GR}_{\text {drug }} / \mathrm{GR}_{\text {control }}>1$ then it calculates $\%$ ca.

\section{STASTISTICAL ANALYSIS}

Statistical analyses were performed using the nonparametric Kruskal-Wallis $\mathrm{H}$ and Mann-Whitney U tests. Kruskal-Wallis one way analysis of variance was used to test for differences among more than two independent samples. Mann-Whitney U allows assume that two independent samples come from populations having the same distribution. A probability $p<0.05$ was considered indicative of statistical significance.

\section{RESULTS}

\section{IN VIVO PHARMACOLOGICAL EFFECT}

$\mathrm{F}$ ig. 1 shows the pharmacological effect of 4 metamizol, piroxicam, or S-AMET in a preinfection treatment of 10 days on the pathological manifestations (a) and pathogenicity index (PI) of T. vaginalis (b) in a murine intraperitoneal model. In this experimental trichomoniasis model, the lesions with the highest score are usually those found in spleen/pancreas/stomach, while ascites renders the lowest values. Only the liver lesions in both sides (visceral and diaphragmatic) have shown a significantly decrease after treatment with metamizol, piroxicam, or S-AMET. In this case, the parameter mortality contributes to PI so much as the abdominal lesions do. Analysis of variance by Kruskal-Wallis $\mathrm{H}$ test indicated that the three experimental groups of treatments show statiscally different PI. Preinfection treatment with piroxicam $(10 \mathrm{mg} / \mathrm{kg} /$ day $)$, or metamizol $(275 \mathrm{mg} / \mathrm{kg} /$ day), diminishes significantly the PI compared with untreated group (control). But, PI of treated group with S-AMET $(17 \mathrm{mg} / \mathrm{kg} / \mathrm{day})$ shows not significant difference when compared to the PI of control group, according to U Mann-Whitney test.

\section{IN VITRO TRICHOMONICIDAL ACTIVITY}

Trichomonicidal activity of piroxicam, metamizol, and S-AMET were tested in vitro at the concentration of $300 \mu \mathrm{M}$, but found ineffective (Table II). Only piroxicam exhibits a weak cytostatic effect (growth inhibition) around $40 \%$.
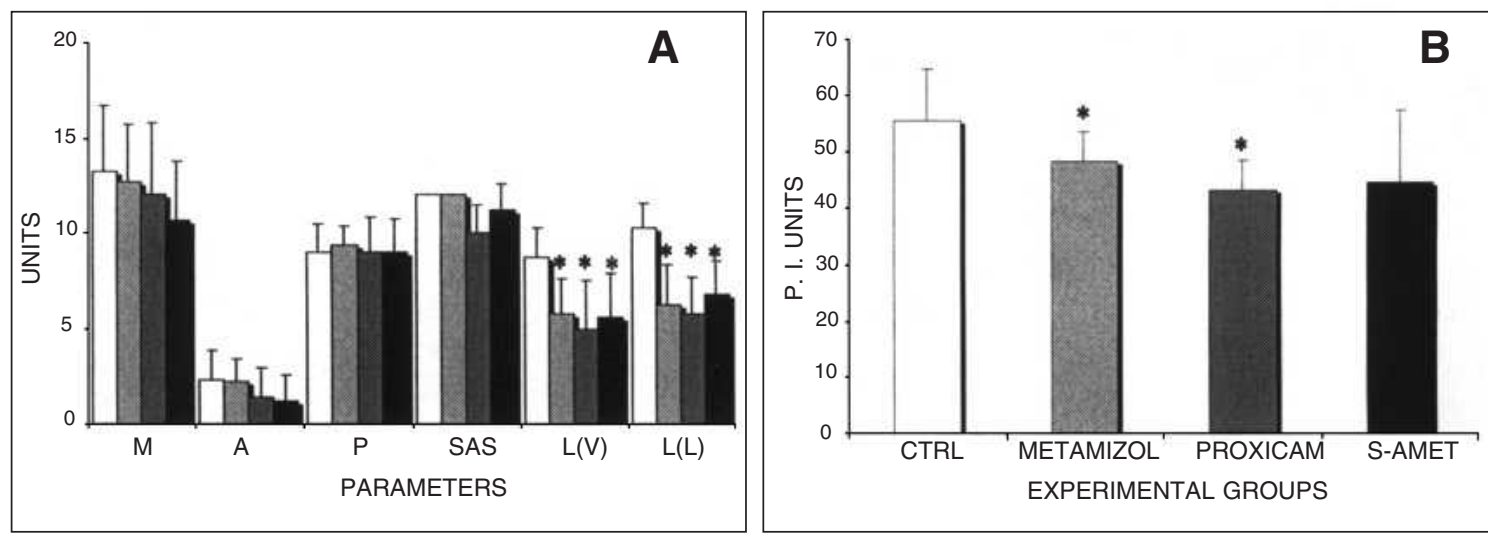

Fig. 1 - Values assigned to the pathologic manifestations (A) and pathogenicity indices (B) in mice treated with different drugs (metamizol, piroxicam, and S-adenosylmethionine) and infected with Trichomonas vaginalis, as expressed by the arithmetic means and the standard error (two independent experiments). The asterisk (*) shows significant differences when compared to the control group by Mann-Whitney $\mathrm{U}$ test $(\mathrm{p}<0.05)$.

Abbreviations: M: mortality, A: ascites, P: peritoneum, S/P/S: spleen/pancreas/stomach, L(V): visceral liver side, L(D): diaphragmatic liver side, CTRL: control group. 


\begin{tabular}{lccc}
\hline & & \multicolumn{2}{c}{ Trichomonicidal } \\
Drugs & Conc $(\mathbf{\mu M})$ & $\mathbf{2 4} \mathbf{~ h}$ & $\mathbf{4 8 ~ h}$ \\
\hline Piroxicam & 300 & 42.7 & 39.3 \\
Metamizol & 300 & 3.5 & 2.2 \\
S-adenosylmethionine & 300 & 2.7 & 0 \\
Metronidazole & 12 & $94.9^{*}$ & $99.2^{*}$ \\
& 6 & $92.4^{*}$ & $97.5^{*}$ \\
& 3 & 48.1 & 25.7 \\
\hline
\end{tabular}

Table II. - In vitro cytostatic or cytocidal (*) activity of piroxicam, metamizol, and S-adenosylmethionine against Trichomonas vaginalis. Values are averages of two independent experiments with six replicates/concentration.

\section{DISCUSSION}

Tr n a previous paper (Nogal-Ruiz et al., 2003a), we have postulate that the development of abdominal lesions in our murine model of experimental trichomoniasis is compatible with a inflammatory phenomenon regulated by neutrophils (Rein et al., 1980), macrophages (Landolfo et al., 1980), and lymphocytes (Th1 cells) fundamentally, with lesser contribution of Th2 cells. Therefore, this may be a suitable experimental model to evaluate the immunomodulating effect of natural or synthetic drugs.

In this paper, we have administrated several drugs to know its pharmacological effect. An intraperitoneal treatment during 10 preinfection days with piroxicam (10 mg/Kg/day), or metamizol (275 mg/Kg/day), but not with S-AMET (17 mg/Kg/day), induced a significant decrease of abdominal lesions and mortality, assessed by means of a pathogenicity index previously established.

Piroxicam as NSAID exhibits such effects mainly through inhibition of the cyclo-oxygenase pathway of arachidonate metabolism, including prostaglandins, thromboxanes and leukotrienes (Vane, 1971), as well as the inhibition of the production of inflammatory cytokines (Chang et al., 1990), and different membraneassociated processes (Abramsom et al., 1989). In our experimental model, the mice treated with piroxicam have shown the down-regulation of cell-mediated immunity (destruction of infected cells by NK cells, cytotoxic $\mathrm{T}$ cells, and activated macrophages), which impedes the formation of gross necrotic foci in abdominal organs, especially in the liver.

On the other hand, metamizol as inhibitor of the cyclo-oxygenase enzyme (Lüthy et al., 1983) produces an inhibition of the IL- 4 release, and $\mathrm{PGE}_{2}$ production. Also, this drug seems to induce an increase of IL-2 and IL-10 production. Such mechanism, inhibiting proinflammatory cytokine release, may be a pathway to explain its anti-inflammatory effect and the concomitant decrease of abdominal lesions in our model.

By contrast, assuming that it seems well based the arguments that attribute to S-AMET immunomodulating properties: a increase of S-AMET metabolic products (intracellular glutathione and plasmatic cysteine) has been correlated with higher percentages of $\mathrm{CD}^{+}$ T-cells (Kinscherf et al., 1994) and the cytotoxic T-cells activation (Multhoff et al., 1996), the minimum pharmacological effect observed in our experimental trichomoniasis model is not explained well. However, Thong et al. (1987) have indicated the potential participation of S-AMET in metabolic activation of T.vaginalis that would to balance the stimulation of host immune system. Having established the relation between S-AMET and different metabolic pathways, it is possible hypothesise that potential effect of the drug in the murine model has partially been masked by the activation of such pathways and its relation with pathogenic expression.

Likewise, in vitro trichomonicidal activity of piroxicam, metamizol, and S-AMET have shown an ineffective result at the concentration of $300 \mu \mathrm{M}$. Therefore, the pharmacological effects observed in vivo on the pathogenicity of $T$. vaginalis are due to the modulation of host immune response.

In conclusion, this work has shown the versatility of our murine model of experimental trichomoniasis for the evaluation of immunomodulating activity of synthetic products. Besides, in our experimental conditions, piroxicam and metamizol induce a significant decrease of the PI of the mice treated in experimental groups when compared to the untreated control group, and S-AMET treatment not affects significantly the PI because of the metabolic activation of T. vaginalis.

\section{ACKNOWLEDGEMENTS}

This research was partially supported by ASAC Pharmaceutical International A.I.E. (Alicante, Spain). All animal experiments were carried out according to the European Council on applied animals experiments, published in the Guidelines 86/609 EC, and controlled in Spain by Royal Decree 223/1988 of $14^{\text {th }}$ March, on the protection of animals used for research and other scientific ends.

\section{REFERENCES}

Abramson S.B. \& Weissmann G. The mechanisms of action of nonsteroidal antiinflammatory drugs. Arthritis Rheumatoid, 1989, 32, 1-9. 
Cavier R.E., Gobert J.G. \& Savel J. Application d'une méthode d'infestation intrapéritonéale de la souris par Trichomonas vaginalis à l'étude pharmacologique des trichomonacides. Annales Pharmaceutiques Françaises, 1972, 30, 637-642.

Chang D.M., Baptiste P. \& Schur P. The effect of antirheumatic drugs on IL-1 activity and IL-1 inhibitor production by human monocytes. Journal of Rheumatology, 1990, 17, 1148-1157.

Heine P. \& McGregor J.A. Trichomonas vaginalis: a reemerging pathogen. Clinical Obstetrics and Gynecology, 1993, 36, 137-144.

Herrero A., Ochoa C., Atienza J., Escario J.A., Gomez-Barrio A. \& Martinez-Fernandez A.R. Synthesis and antiprotozoal properties of 1, 2, 6-thiadiazine 1, 1-dioxide derivatives. Archiv der Pharmazie, 1992, 325, 509-514.

Kinscherf F., Fischbach T. \& Minm S. Effect of glutathione depletion and oral N-acetyl-cysteine treatment on CD-4 + and CD-8 + cells. FASEB Journal, 1994, 8, 448-451.

KuLDA J. Employment of experimental animals in studies of Trichomonas vaginalis infection. In: Trichomonads Parasitic in Humans. Honigberg B.M. (ed.), Springer-Verlag, New York, USA, 1990, 112-154.

Landolfo S., MartinotTi M.G., Martinetto P. \& Forni G. Natural cell mediated cytotoxicity against Trichomonas vaginalis. I. Tissue, strain, age distribution, and some characteristic of the effector cells. Journal of Immunology, 1980, $124,508-514$

Levy M., Zylber-Katz E. \& Rosenkranz B. Clinical pharmacokinetics of dypirone and its metabolites. Clinical Pharmacokinetics, 1995, 28, 216-234.

Lüthy C., Multhaupt M., Oetliker O. \& Perisic M. Differential effect of acetylsalicylic acid and dipyrone on prostaglandin production in human fibroblast cultures. British Journal of Pharmacology, 1983, 79, 849-854.

Multhoff G., Boztler C., Allenbacher A. \& Issels R. Effects of ifosfamide on immunocompetent effector cells. Cancer Immunology Immunotherapy, 1996, 42, 251-254.

Nogal-Ruiz J.J., Escario J.A., Martinez-Diaz R.A. \& GomezBARRIO A. Evaluation of a murine model of experimental trichomoniasis. Parasite, 1996, 2, 127-132.

Nogal-Ruiz J.J., Gomez-Barrio A., Escario J.A. \& Martinez-FerNANDEZ A.R. Modulation by Polypodium leucotomos extract of cytokine patterns in experimental trichomoniasis model. Parasite, 2003a, 10, 73-78.

Nogal-Ruiz J.J., Gomez-Barrio A., Escario J.A. \& Martinez-FerNANDEZ A.R. Effect of Anapsos ${ }^{\circledR}$ in a murine model of experimental trichomoniasis. Parasite, 2003b, 10, 303-308.

Rein M.F., Sullivan J.A. \& Mandell G.L. Trichomonicidal activities of human polymorphonuclear neutrophils: Killing by disruption and fragmentation. Journal of Infectious Diseases, 1980, 142: 575-585.

TABOR C.W. \& TABOR H. Methionine adenosyltransferase (Sadenosylmethionine synthetase) and S-adenosylmethionine decarboxylase. Advances of Enzymology, 1984, 56, 251-282.

Teras J. \& Roigas E. Characteristic of the patho-morfological reaction in cases of experimental infection with Tri- chomonas vaginalis. Wiadomosci Parazytologiczne, 1966, $12,161-172$

Thong K.W., Coombs G.H. \& Sanderson B.E. S-adenosylmethylation reactions in trichomonads. Parasitology Research, 1987, 73, 193-198.

VANE J.R. Inhibition of prostaglandin synthesis as a mechanism of action for aspirin-like drugs. Nature, 1971, 231, 232-235.

WALKER J. \& BARRET J. Parasite sulphur amino acid metabolism. Internacional Journal for Parasitology, 1997, 27, 883-897.

Reçu le 28 septembre 2004 Accepté le 8 novembre 2004 